\title{
Pengembangan Soal Matematika Bernuansa Islami
}

\author{
Nunung Sobarningsih', Juariah², Rikrik Nurdiansyah3, \\ Ayu Retno Purwanti4, dan Rahayu Kariadinata5 \\ Prodi Pendidikan Matematika, UIN Sunan Gunung Djati Bandung \\ JL. Soekarno Hatta, Gedebage, Kota Bandung \\ juariah@uinsgd.ac.id
}

Received: 12 September 2019; Accepted: 22 November 2019; Published: 29 Desember 2019

\begin{abstract}
Abstrak
Tujuan penelitian ini adalah mengembangkan soal matematika bernuansa Islami atau soal terintegrasi. Maksud terintegrasi disini merupakan keterhubungan antara matematika dengan kehidupan sehari-hari berlandaskan nilai-nilai Islami. Jenis penelitian ini merupakan penelitian research and development $(R \& D)$ dengan subjek penelitian adalah siswa kelas VIII salah satu Madrasah Tsanawiyah di Kota Bandung dan Kabupaten Majalengka dan Sukabumi. Instrumen penelitian terdiri dari seperangkat soal bernuansa Islami dan angket. Berdasarkan hasil penelitian diperoleh bahwa soal matematika bernuansa Islami telah memiliki kriteria soal yang baik melalui tahapan (R\&D) sehingga layak untuk digunakan. Peserta didik merespon baik terhadap soal bernuansa Islami. Bagi peserta didik dan guru meskipun hal baru namun soal tersebut memberikan manfaat yang lebih bermakna akan adanya soal terintegrasi yang diharapkan tertanam nilai-nilai karakter yang baik.
\end{abstract}

Kata kunci: Matematika Terintegrasi

\begin{abstract}
The purpose of this research is to develop mathematical problems with Islamic nuance or integrated problems. The integrated intention here is the connection between mathematics and daily life based on Islamic values. This type of research is a research and development $(R \& D)$ research with the subject of research is a class VIII student of one of the Tsanawiyah Madrasah in Bandung City and Majalengka, and Sukabumi Regency. The research instrument consisted of a set of questions nuanced Islamic and questionnaire. Based on the results of the study, it was found that mathematical questions with Islamic nuance had good question criteria through the stages (R\&D) so that it was feasible to use. Students respond well to questions about Islamic nuance. For students and teachers, although this is new, the question provides more meaningful benefits of integrated problems that are expected to be embedded with good character values.
\end{abstract}

Keywords: Integrated Mathematics 
Nunung Sobarningsih, Juariah

Rikrik Nurdiansyah, Ayu Retno Purwanti

Rahayu Kariadinata

\section{PENDAHULUAN}

Pendidikan islam mengajarkan nilai-nilai yang dapat membentukan kepribadian berkarakter, berakhlak mulia dan beradab, pendidikan yang berbasis pada nilai-nilai islam akan membentuk kepribadian yang baik. Nilai-nilai islam dapat diintegrasikan dalam proses pembelajaran matematika sehingga dapat mengantarkan siswa untuk mencapai pengetahuan (kognitif), pemahaman dan penerapan nilai-nilai islam Nilai-nilai matematika dapat membangun karakter siswa meliputi sikap sungguhsungguh, teliti, jujur, kerja keras, tekun (Sugilar, Kariadinata, Farlina, \& Gunawan, 2018)(Yusuf, 2013, hal. 4) Penyelenggaraan pendidikan pada tingkat menengah atau madrasah tsanawiyah berdasarkan PP No. 17/2010 tentang pengelolaan dan penyelenggaran pendidikan pada pasal 1 dinyatakan bahwa Madrasah Tsanawiyah, yang selanjutnya disingkat MTs, adalah salah satu bentuk satuan pendidikan formal dalam binaan Menteri Agama yang menyelenggarakan pendidikan umum dengan kekhasan agama Islam pada jenjang pendidikan dasar sebagai lanjutan dari SD, MI, atau bentuk lain yang sederajat atau lanjutan dari hasil belajar yang diakui sama atau setara SD atau MI.

Salah satu komponen penting dalam proses pembelajaran adalah bahan ajar, saat ini bahan ajar yang digunakan juga sudah mulai terintegrasi dengan nilai- nilai yang ada dalam pendidikan agama islam. Selain bahan ajar, instrumen soal juga merupakan salah satu bagian yang penting dalam pelaksanaan pembelajaran di sekolah, karena instrumen digunakan untuk mengukur dan mengevaluasi kemampuan siswa. Menurut Sukmadinata (2010:230) Instrumen penelitian itu adalah berupa tes yang bersifat mengukur, karena berisi tentang pertanyaan dan pernyataan yang alternatif jawabanya memiliki standar jawaban tertentu, baik berupa benar salah maupun skala jawaban. Sedangkan tes adalah cara atau prosedur yang perlu di tempuh dalam rangka pengukuran dan penilaian di bidang pendidikan yang berbentuk serangkaian tugas berupa pertanyaan-pertanyaan yang harus dijawab. (Sudijono, 2011: 67).

Integrasi matematika dengan islam adalah adanya kesinambungan antara matematika dengan islam. Jika dalam pembelajaran matematika adanya kesinambungan antara materi pelajaran matematika dengan islam. Karena matematika membantu umat islam untuk mengamalkan salah satu ilmu yang diajarkan dalam al-Qur'an. (Maarif, 2015) (Mahfudzoh, 2011). Matematika ditinjau dari filosofinya bersumber dari Al Quran. Hal ini dikuatkan oleh banyaknya ayat-ayat dalam AlQuran yang bernuansa berhitung bilangan. Misalnya Surat An-nisa ayat 11 dan 12 yang menegaskan tentang pembagian warisan, Surat An'Aam ayat 96 tentang peredaran matahari dan bulan dapat membantu manusia dalam melakukan perhitungan, dan banyak ayat-ayat yang lain (Salafudin, 2015, hal. 227). Tujuan Penelitian ini untuk mengetahui bagaimana proses pengembangan soal bernuansa islami pada pokok bahasan statitiska di kelas VIII Madrasah Tsanawiyah dan bagaimana bentuk soal bernuansa islami pada pokok bahasan statistika yang layak digunakan di kelas VIII Madrasah Tsanawiyah.

\section{METODE}

Penelitian ini menggunakan jenis penelitian research and development. Penelitian pengembangan atau disebut juga dengan research and development (R\&D) yang dikemukakan oleh Sugiyono terdapat sepuluh langkah penelitian pengembangan. 
Pengembangan soal matematika bernuansa islami ini tidak dilanjutkan sampai pada tahap produksi masal, namun hanya sampai pada tahap yang menghasilkan produk akhir, sehingga langkah-langkah penelitian R\&D ini dibatasi dan disesuaikan dengan penelitian. Langkah- langkah penelitian setelah dibatasi sesuai kebutuhan penelitian dapat dilihat pada Gambar 1 berikut.

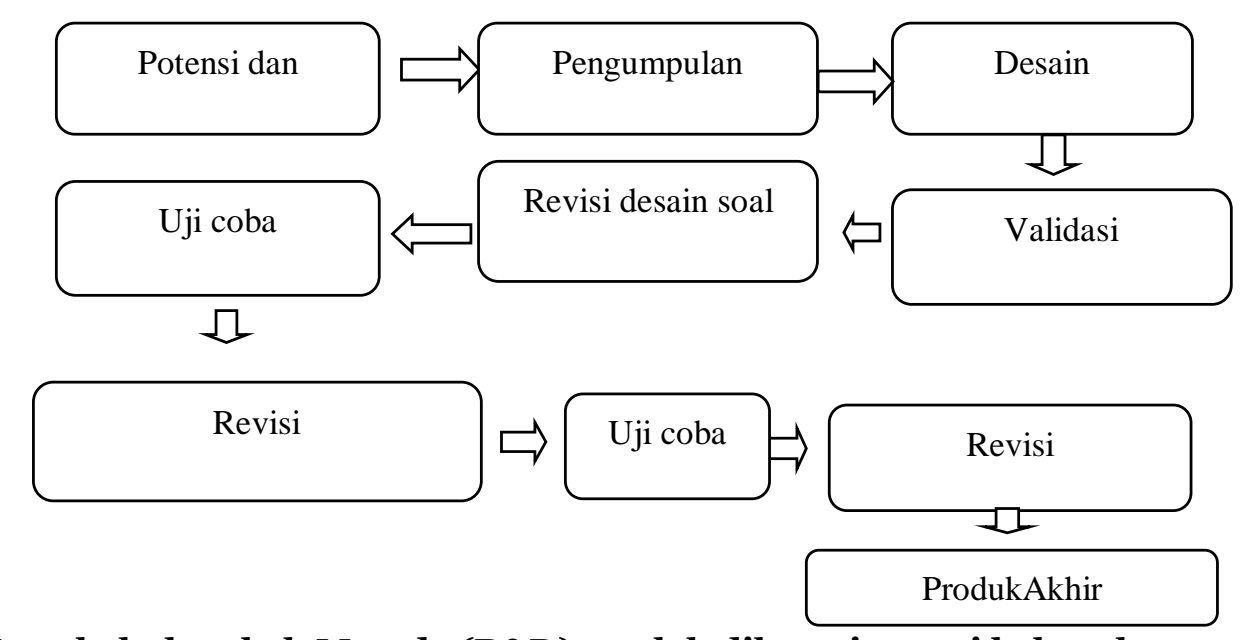

Gambar 1. Langkah- langkah Metode (R\&D) setelah dibatasi sesuai kebutuhan penelitian

Penelitian dilakukan secara bertahap, fase pendahuan dimulai sejak Juli 2019 sampai fase yang paling akhir yaitu uji coba dalam skala besar yang dilakasanakan pada Oktober 2019. Dari mulai fase pendahuluan sampai fase akhir yaitu uji coba dalam skala besar tempat penelitian berada pada MTs di di Majalengka, Bandung dan Sukabumi. Populasi dalam penelitian ini adalah seluruh siswa kelas VIII salah satu MTs di Majalengka, Sukabumi dan Kota Bandung semester ganjil 2019-2020. Sampel pada penelitian ini menggunakan empat kelas, yaitu kelas VIII A, VIII B, VIIIE dan VIII G. Teknik sampling yang digunakan untuk menentukan sampel pada penelitian ini adalah purposive sampling. Data diuji normalitas dan homogenitasnya terlebih dahulu.

Jenis data yang digunakan dalam penelitian ini terdiri dari data primer dan data sekunder. Dimana yang menjadi data primer dalam penelitian ini adalah hasil observasi, hasil lembar validasi ahli hasil dari angket respon siswa terhadap soal matematika bernuansa islami dan hasil pengerjaan soal dari soal matematika bernuansa islami. Sedangkan data sekunder dalam penelitian ini merupakan data yang mendukung keperluan data primer, diantaranya seperti buku- buku, literatur dan bacaan yang berkaitan dengan peneletian pengembangan soal matematika bernuansa islami. Instrumen yang digunakan dalam penelitian ini berupa lembar validasi, lembar angket dan lembar soal.

\section{HASIL DAN PEMBAHASAN}

\section{Pembelajaran Matematika yang Bernuansa Islam}

Pembelajaran matematika bernuansa nilai-nilai islam selain mempunyai tujuan agar tercapainya pemahaman dan kemampuan 
Nunung Sobarningsih, Juariah

Rikrik Nurdiansyah, Ayu Retno Purwanti

Rahayu Kariadinata

matematika siswa, juga dimaksudkan untuk menanamkan nilai-nilai islam pada siswa. Penanaman itu sendiri berasal dari kata "tanam" yang memiliki arti menaruh, menaburkan, atau memelihara (perasaan, cinta kasih). Sedangkan penanaman itu sendiri memiliki arti proses, cara, atau perbuatan menanamkan. Dengan demikian, penanaman nilai-nilai islam adalah suatu proses untuk menanamkan nilai-nilai islam pada siswa (Salafudin, 2015, hal. 233).

Pembelajaran matematika bernuansa nilai-nilai islami yang dimaksud disini adalah pembelajaran yang dilakukan dengan pemberian nilai-nilai keislaman pada setiap pembelajaran baik berupa materi maupun pada contoh soal. Selain itu, nuansa Islami akan terlihat pada metode pembelajaran yang dilaksanakan. Nilai-nilai Islam yang diintegrasikan ke dalam mata pelajaran matematika meliputi: 1) nilai akidah, 2) nilai syari'ah, dan 3) nilai akhlak (Salafudin, 2015)

Materi statistika telah dikenal oleh peserta didik sejak kelas VII Madrasah tsanawiyah, tetapi materi statistika ini lebih diperdalam lagi dikelas VIII. Karena kompetensi dasar satistika di kelas VII hanya sampai pada penyajian data. Berikut akan diberikan contoh bentuk soal statistika yang bernuansa islami. Pada materi statistika ada beberapa ilmu agama ataupun nilai- nilai keislaman yang dapat diintegrasikan dengan materi statistika, karena materi statistika selalu berhubungan dengan berbagai data maka cukup banyak nilai- nilai keislaman yang dapat dijadikan konten dalam soal soal bernuansa islami, seperti zakat, sedekah, puasa, jumlah huruf dan ayat dalam surat al-qur'an, hukum bacaan dalam al-qur'an dan masih banyak lagi nilai- nilai keislaman lainnya yang dapat diintegrasikan dengan materi statistika.
Penelitian yang relevan dengan pengembangan soal bernuansa islami ini pernah dilakukan oleh Ani Rahmawati dan Swaditya Rizki pada tahun 2017 dengan judul "Pengembangan Bahan Ajar Matematika Berbasis Nilai-Nilai Islam Pada Materi Aritmatika Sosial". Tujuan dari penelitian dan pengembangan ini adalah untuk mengembangkan bahan ajar matematika tentang aritmatika sosial berdasarkan nilai-nilai Islam yang layak, praktis, dan efektif. Jenis penelitian ini adalah Penelitian dan Pengembangan (R\&D). Model yang digunakan Dalam penelitian ini terdiri dari 10 tahap. Instrumen pengumpulan data menggunakan pertanyaan kuesioner dan evaluasi. Kuesioner terdiri dari desain, materi, dan konten Islami. Hasil penelitian adalah rata - rata validasi Persentase 82,3\%, sehingga bahan ajar dikategorikan layak. Berdasarkan Proses validasi menunjukkan bahwa materi ajar yang dikembangkan termasuk kategori layak, dengan persentase rata-rata adalah $82,3 \%$. Sedangkan hasil kecil Uji coba kelompok menunjukkan bahwa tanggapan siswa pada tahap percontohan kelompok kecil 16 siswa diperoleh $87,5 \%$, dan hasil dari tes tersebut didapat ratarata lebih dari $75 \%$ siswa yang mendapat nilai lebih dari standar 75,00. Dari Hasil penelitian ini dapat disimpulkan bahwa materi ajar aritmatika sosial layak, praktis, dan efektif.

Penelitian ini akan mengembangakan suatu produk berupa soal matematika bernuansa islami untuk materi pembelajaran kelas VIII semester ganjil. Untuk mendapatkan soal matematika bernuansa islami peneliti melaksanakan proses pembelajaran matematika bernuansa islami terlebih dahulu, setelah itu barulah peneliti membuat soal matematika bernuansa islami yang akan digunakan untuk mengevaluasi hasil belajar siswa. Hal didasarkan pada belum adanya soalsoal bernuansa islami yang digunakan oleh guru 
untuk mengevaluasi hasil belajar siswa di MTs Kabupaten Sukabumi, Majalengka dan Kota Bandung. Faktor lain penelitian ini adalah ingin mengetahui kesiapan guru dalam menyiapkan materi pembelajaran matematika yang terintegrasi atau bernuansa Islami agar peserta didik dapat merasakan manfaat matematika dalam kehidupan sehari-hari dan mengetahui keterkaitan matematika pada AlQur'an. Tentu hal ini bukan dipaksakan atau dengan sengaja menghubungkan matematika dengan AlQur'an namun lebih pada menghayati akan kekuasaan dan kebesaran Alloh tentang ciptaanNya yang dikaitkan atau diintegrasikan dengan matematika.

Alur berpikir peneliti dapat dilihat melalui Gambar 2. berikut.

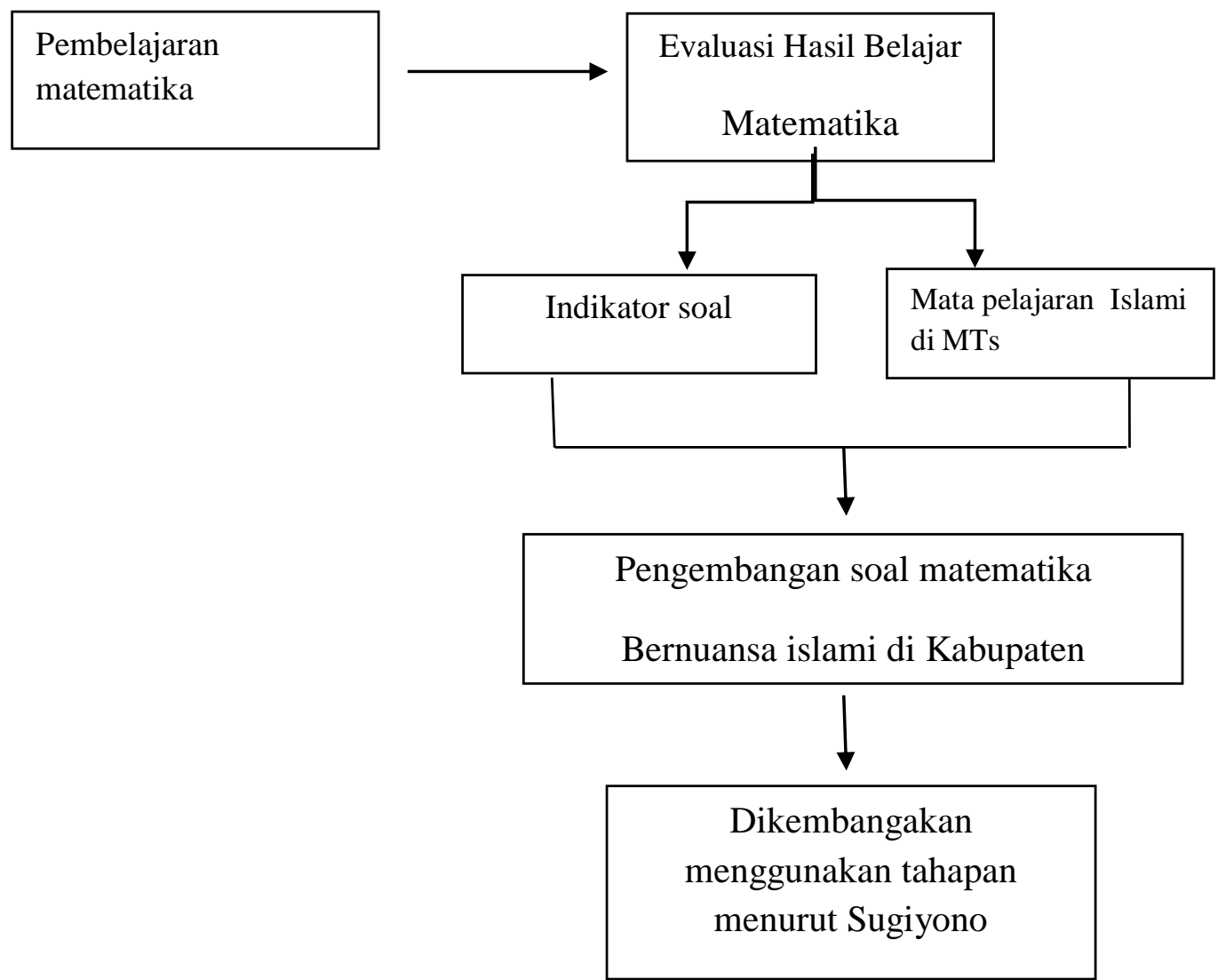

Gambar 2. Skema Kerangka

Berdasarkan observasi langsung pada salah satu madrasah di Kota Bandung dan hasil diskusi dengan guru mata pelajaran matematika kelas VIII, peneliti memperoleh beberapa informasi, diantaranya proses pembelajaran matematika sudah berkaitkan dengan nilai- nilai islam ketika guru memberikan contoh dalam kehidupan sehari-hari hanya untuk bahan ajar dan soal yang digunakan belum bernuansa islami dan ini merupakan hal baru.

\section{Pengumpulan Data}

Pada tahapan pengumpulan data, kegiatan yang dilakukan adalah mengumpulkan data-data yang dijadikan sumber dan yang dibutuhkan 
Nunung Sobarningsih, Juariah

Rikrik Nurdiansyah, Ayu Retno Purwanti

Rahayu Kariadinata

untuk penyusunan soal matematika bernuansa islami. Data-data yang dikumpulkan seperti buku paket yang memuat materi statistika untuk dijadikan referensi materi dan kurikulum yang digunakan untuk menjabarkan standar kompetensi yang harus dicapai siswa, sebelum membuat dan memberikan soal matematika bernuansa islami, siswa harus sudah menguasai materi yang akan disajikan dalam soal. Sebelum membuat kisi-kisi dan soal bernuansa islami ada proses pembelajaran yang dilakukan sebanyak dua pertemuan dengan menggunakan LKPD sebagai bahan ajar dan alat untuk mengetahui kepahaman siswa terhadap materi yang akan disajikan dalam soal. Akan tetapi proses pembelajaran pada materi statistika hanyak dilakukan pada satu kelas yaitu kelas VIII-B yang digunakan untuk dijadikan patokan pembuatan kisi- kisi dan soal matematika bernuansa islami dari 4 kelas yang akan digunakan untuk menguji coba soal matematika bernuansa islami.

\section{Desain Soal}

Pada tahapan desain produk kegiatan yang dilakukan adalah membuat kisi-kisi dan soal matematika bernuansa islami yang terdiri dari 10 soal pilihan ganda dan 10 soal uraian.

\section{Validasi Desain Soal}

Sebelum digunakan untuk uji coba dalam skala kecil soal matematika bernuansa islami harus mempunyai status "valid". Idealnya saat mengembangkan soal perlu melalukan pemeriksaan ulang kepada para ahli (validator) mengenai ketepatan isi materi pembelajaran, kontruksi soal, dan bahasa yang digunakan pada soal sehingga dinilai baik oleh validator. Proses validasi diharapkan dapat memberikan penilaian yang layak pada soal matematika bernuansa islami agar dapat digunakan untuk proses pembelajaran. Yakni dengan mendapatkan status valid atau sangat valid dari para ahli. Jika soal belum valid, maka validasi akan terus dilakukan hingga didapatkan soal yang valid. Dalam penelitian ini, proses rangkaian validasi dilaksanakan sebanyak 2 kali validasi ahli materi karena pada saat validasi pertama soal matematika bernuansa islami masih memiliki banyak keselahan sehingga dilakukan revisi terlebih dahulu agar soal dapat dinilai valid. Adapun validator soal matematika bernuansa islami yaitu mereka yang berkompeten dan mengerti tentang soal matematika bernuansa islami dan mampu memberi masukan/saran untuk menyempurnakan soal yang telah disusun. Saran-saran dari validator tersebut akan dijadikan bahan untuk merevisi soal matematika bernuansa islami.

Kegiatan validasi soal ini juga menghasilkan penilaian mengenai kepraktisan soal. Penilaian kepraktisan ini bertujuan untuk mengetahui apakah soal ini layak digunakan untuk pembelajaran. Soal dikatakan praktis jika validator menyatakan bahwa soal ini layak digunakan tanpa revisi atau sedikit revisi. Hasil validasi dari tiga validator menunjukkan bahwa soal matematika bernuansa islami sudah baik setelah melewati beberapa tahapan revisi. Secara garis menurut tiga validator, kekurangan soal matematika bernuansa islami sebelum direvisi adalah pada redaksi kata yang digunakan dalam soal dan penggunaan diagram yang kurang tepat dengan data yang disajikan. Untuk lebih jelasnya hasil validasi oleh materi ini akan dipaparkan secara rinci pada saat pemaparan revisi desain soal.

\section{Revisi Desain Soal}

Pada tahapan revisi desain kegiatan yang dilakukan adalah merevisi soal matematika 
bernuansa islami yang telah disarankan oleh validator pada saat validasi untuk mengahasilkan soal yang layak digunakan dalam proses uji coba. validasi pertama soal matematika bernuansa islami masih memiliki banyak keselahan sehingga dilakukan revisi terlebih dahulu agar soal dapat dinilai valid. Oleh validator ke-1 dan ke-3 soal direvisi sebanyak 1 kali, sedangkan oleh validator ke-2 soal direvisi sebanyak 2 kali sampai soal matematika bernuansa islami.

\section{Temuan Terkait Proses Pengembangan Soal Matematika Bernuansa Islami}

Proses pengembangan soal matematika bernuansa islami terdapat beberapa hal yang menarik. Temuan tersebut seperti terdapat dalam proses penyusunan kisi-kisi soal matematika bernuansa islami. Pada saat penyusunan kisi-kisi ada beberapa kesulitan yang dialami, seperti dalam menyesuaikan soal dengan kisi-kisi yang telah di susun. Sedangkan menurut Syofyan (2016, hal. 14) penulisan kisikisi berfungsi untuk menselaraskan perangkat soal, sehingga hal ini juga akan mempermudah dalam proses evaluasi. Kisi-kisi yang baik harus dapat mewakili silabus atau kurikulum, komponen-komponennya diuraikan secara jelas dan materi yang hendak ditanya dapat dibuatkan soal.

Temuan selanjutnya adalah pada saat validasi dengan ahli materi. Menurut validator, redaksi kata yang digunakan pada soal matematika bernuansa islami tidak praktis dan masih ada beberapa susunan kalimat yang kurang tepat dan tidak mudah dipahami. Sehingga harus melewati tahapan revisi terlebih dahulu sebelum diujicobakan. Karena menurut Kadir (2015, hal. 73) pokok soal dan pilihan jawaban harus dirumuskan secara jelas, singkat, padat,dan tegas, sehingga perumusan tersebut hanya mencakup pernyataan yang diperlukan saja.

Faktor penyebab kurang baiknya validitas pada hasil jawaban siswa terhadap soal matematikan bernuansa islami juga menjadi temuan dalam proses pengembangan, karena dari hasil uji coba skala kecil yang telah dianalisis masih ada beberapa butir soal yang kurang baik. Ada bebarapa kemungkinan yang menjadikan soal tersebut memiliki validitas dengan penafsiran kurang diantaranya yaitu adanya soal yang dianggap sukar oleh siswa sehingga faktor tebakan pada soal pilihan ganda banyak berperan, adanya soal yang dianggap terlalu mudah oleh siswa sehingga siswa kurang teliti dan cenderung menyepelekan soal tersebut, dan adanya pembatasan waktu dalam mengerjakan soal sehingga mempengaruhi siswa untuk menjawab soal dengan cepat namun tidak tepat. Secara garis besar masih banyak faktor yang membuat soal matamatika bernuansa islami ini perlu beberapa tahapan perbaikan agar menghasilkan soal yang layak dijadikan sebagai produk akhir pada pengembangan soal matematika bernuansa islami.

\section{Temuan Terkait Kelayakan Soal Matematika Bernuansa Islami}

Kelayakan soal matematika bernuansa islami dilihat dari nilai yang diberikan oleh para ahli materi mengenai kelayakan soal matematika bernuansa islami dengan menilai beberapa aspek dari soal yang telah dibuat, yakni aspek materi, kontruksi dan bahasa. Hasil dari validasi ahli materi dapat memperbaiki ketiga aspek pada soal sebelum soal diujicobakan dalam skala kecil kepada siswa kelas VIII-D di MTs di Kota Bandung. Dalam penilaian kelayakan soal matematika bernuansa islami validator ngemukakan bahwa dari aspek bahasa masih kurang sesuai dengan aspek yang 
Nunung Sobarningsih, Juariah

Rikrik Nurdiansyah, Ayu Retno Purwanti

Rahayu Kariadinata

diharapkan, karena ada beberapa butir soal pilihan ganda ataupun soal uraian masih menggunakan rumusan kalimat yang kurang komutatif. Aspek lain yang masih perlu diperbaiki adalah aspek kontruksi, karena grafik yang digunakan pada beberapa soal pilihan ganda masih kurang tepat. Sehingga soal matematika bernuansa islami masih harus melalui tahapan revisi untuk mendapatkan penilaian yang layak. Setelah melalui tahapan revisi validator menilai bahwa soal matematika bernuansa islami sudah layak diujicobakan.

Kelayakan soal matematika bernuansa islami selanjutnya dinilai dari reliabilitas dan validitas soal, hal ini sesuai dengan ciri-ciri tes yang baik menurut Basuki (2014, hal. 22) bahwa suatu tes yang baik diketahui memiliki ciri-ciri pokok antara lain, dapat dipercaya (reliable), sah atau valid, objektif, serta praktis. Reliabilitas pada soal matematika bernuansa islami sudah reliable baik soal pada uji coba terbatas maupun pada uji coba skala besar, bahkan berdasarkan hasil jawaban siswa dari soal matematika bernuansa islami soal pada uji skala besar lebih reliable dari pada soal pada uji coba terbatas. Validitas soal matematika bernuansa islami pada uji coba terbatas masih ada 6 butir soal yang memiliki validitas dalam kategori rendah, sedangkan untuk validitas pada uji coba dalam skala besar semua butir soal sudah memiliki validitas yang cukup, baik dan sangat baik. Daya pembeda pada uji coba terbatas ada 4 butir soal dengan kategori buruk, sedangkan daya pembeda pada uji coba skala besar semua butir soal sudah memiliki daya pembeda yang baik.

Berdasarkan beberapa hal yang telah dijelaskan, dapat disimpulkan bahwa soal matematika bernuansa islami sudah baik dan layak digunakan di kelas VIII MTs Kabupaten Majalengka, Sukabumi dan Kota Bandung.

\section{Temuan terkait Respon Siswa Terhadap Soal Matematika Bernuansa Islami}

Respon siswa merupakan suatu reaksi dari siswa setelah mengerjakan soal matematika bernuansa islami. Respon siswa dalam menanggapi soal matematika bernuansa islami ada dua macam yakni respon positif (senang) dan respon negatif (tidak senang). Hal ini dapat diukur dengan ketertarikan, manfaat yang dirasakan, kendala yang dihadapi dan harapan siswa tentang soal matematika bernuansa islami (Kusuma, 2012, hal. 49). Rata-rata respon siswa terhadap soal matematika bernuansa islam mendapatkan lebih banyak respon positif dibandingakan dengan respon negatif, yang mana respon positif sebesar $76,75 \%$ dan respon negatif sebesar $23,25 \%$.

Hasil respon siswa terhadap soal matematika bernuansa islami, sebanyak $83,50 \%$ siswa menilai bahwa materi yang digunakan pada soal sudah dipahami dan dikuasai oleh siswa. Sama halnya seperti menurut Basuki (2014, hal. 27) Salah satu tujuan dari tes adalah memperbaiki proses pembelajaran serta memahami sampai sejauh mana kemampuan siswa menafsirkan dan menguasai bahan ajar. Nilai ini diperoleh karena soal matematika bernuansa islami sesuai dengan materi yang di peroleh pada saat pembelajaran sehingga siswa dapat memahami soal dengan baik. Selain materi yang digunakan pada soal harus sudah dikuasai oleh siswa, pengajar juga dituntut untuk senantiasa memberikan perangkat pembelajaran yang menarik. Dalam hasil analisis respon siswa , sebanyak 82,25\% siswa memberikan respon bahwa mereka tertarik dengan soal matematika bernuansa islami. Ketertarikan tersebut dapat meningkatkan motivasi dengan menarik perhatian siswa. Salah satu tujuan dari tes adalah harus meningkatkan motivasi siswa karena siswa yang kompeten dan sadar akan 
tugasnya sebagai pelajar akan membuat hasilhasil tesnya menjadi lebih baik (Basuki, 2014, hal. 28).

Kisi-kisi soal matematika disusun berdasarkan indikator yang sesuai dengan Kompetensi Inti dan Kompetensi Dasar kurikulum 2013 yang digunakan di MTs Kabaupaten Sukabumi dan Kota Bandung sehingga meskipun konten yang digunakan pada soal bernuansa islami dan diintegrasikan dengan materi agama, soal matematika bernuansa islami tetap membuat siswa dapat memahami soal dengan baik dan membuat siswa merasa diingatkan kembali mengenai materi agama islam yang sudah mereka pelajari seperti terlihat pada hasil respon siswa pada pernyataan nomor 3 yaitu sebanyak $83,50 \%$ siswa yang merespon secara positif. Secara garis besar soal matamatika bernuansa islami ini menarik perhatian siswa dalam mengerjakan soal dan soal dapat dipahami siswa dengan baik.

Tabel 1. Hasil Validasi Soal Matematika Bernuansa Islami Oleh Ahli Materi

\begin{tabular}{|c|c|c|c|c|c|}
\hline $\begin{array}{l}\frac{\pi}{0} \\
\frac{0}{2} \\
\frac{2}{2}\end{array}$ & $\stackrel{0}{\mathbf{z}}$ & Kriteria & $\begin{array}{c}\text { Rata- } \\
\text { rata } \\
\text { Seluruh } \\
\text { Soal }\end{array}$ & $\begin{array}{c}\text { Rata- } \\
\text { rata } \\
\text { Tiap } \\
\text { Aspek }\end{array}$ & $\stackrel{\theta}{2}$ \\
\hline & 1 & $\begin{array}{l}\text { Butir soal sesuai } \\
\text { dengan } \\
\text { indikator }\end{array}$ & 3,96 & 3,98 & \\
\hline 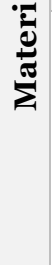 & 2 & $\begin{array}{l}\text { Isi materi sesuai } \\
\text { dengan jenjang, } \\
\text { jenis sekolah, } \\
\text { dan tingkat } \\
\text { kelas }\end{array}$ & 4 & & 寻 \\
\hline
\end{tabular}

\begin{tabular}{|c|c|c|c|c|c|}
\hline 离 & $\ddot{z}$ & Kriteria & $\begin{array}{c}\text { Rata- } \\
\text { rata } \\
\text { Seluruh } \\
\text { Soal }\end{array}$ & $\begin{array}{c}\text { Rata- } \\
\text { rata } \\
\text { Tiap } \\
\text { Aspek }\end{array}$ & 包 \\
\hline & 3 & $\begin{array}{l}\text { Hanya ada satu } \\
\text { kunci jawaban } \\
\text { atau jawaban } \\
\text { yang benar }\end{array}$ & 4 & & \\
\hline \multirow{5}{*}{ 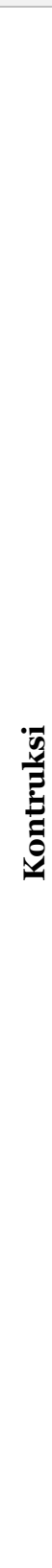 } & 4 & $\begin{array}{l}\text { Rumusan soal } \\
\text { dan pilihan } \\
\text { dirumuskan } \\
\text { dengan jelas }\end{array}$ & 3,83 & \multirow[t]{5}{*}{3,83} & \multirow{5}{*}{ 恋 } \\
\hline & 5 & $\begin{array}{l}\text { Pokok soal tidak } \\
\text { memberi } \\
\text { petunjuk/meng } \\
\text { arah kepada } \\
\text { pilihan jawaban } \\
\text { yang benar }\end{array}$ & 3,93 & & \\
\hline & 6 & $\begin{array}{l}\text { Pilihan jawaban } \\
\text { homogen }\end{array}$ & 3,90 & & \\
\hline & 7 & $\begin{array}{l}\text { Hindari adanya } \\
\text { alternatif } \\
\text { jawaban: } \\
\text { "seluruh } \\
\text { jawaban di atas } \\
\text { benar" atau "tak } \\
\text { satu jawaban di } \\
\text { atas benar" dan } \\
\text { yang sejenisnya }\end{array}$ & 3,89 & & \\
\hline & 8 & $\begin{array}{l}\text { Panjang } \\
\text { alternatif/piliha } \\
\mathrm{n} \text { jawaban } \\
\text { relatif sama, } \\
\text { tidak ada yang } \\
\text { sangat panjang } \\
\text { dan ada yang } \\
\text { sangat pendek. }\end{array}$ & 4 & & \\
\hline
\end{tabular}


Nunung Sobarningsih, Juariah

Rikrik Nurdiansyah, Ayu Retno Purwanti

Rahayu Kariadinata
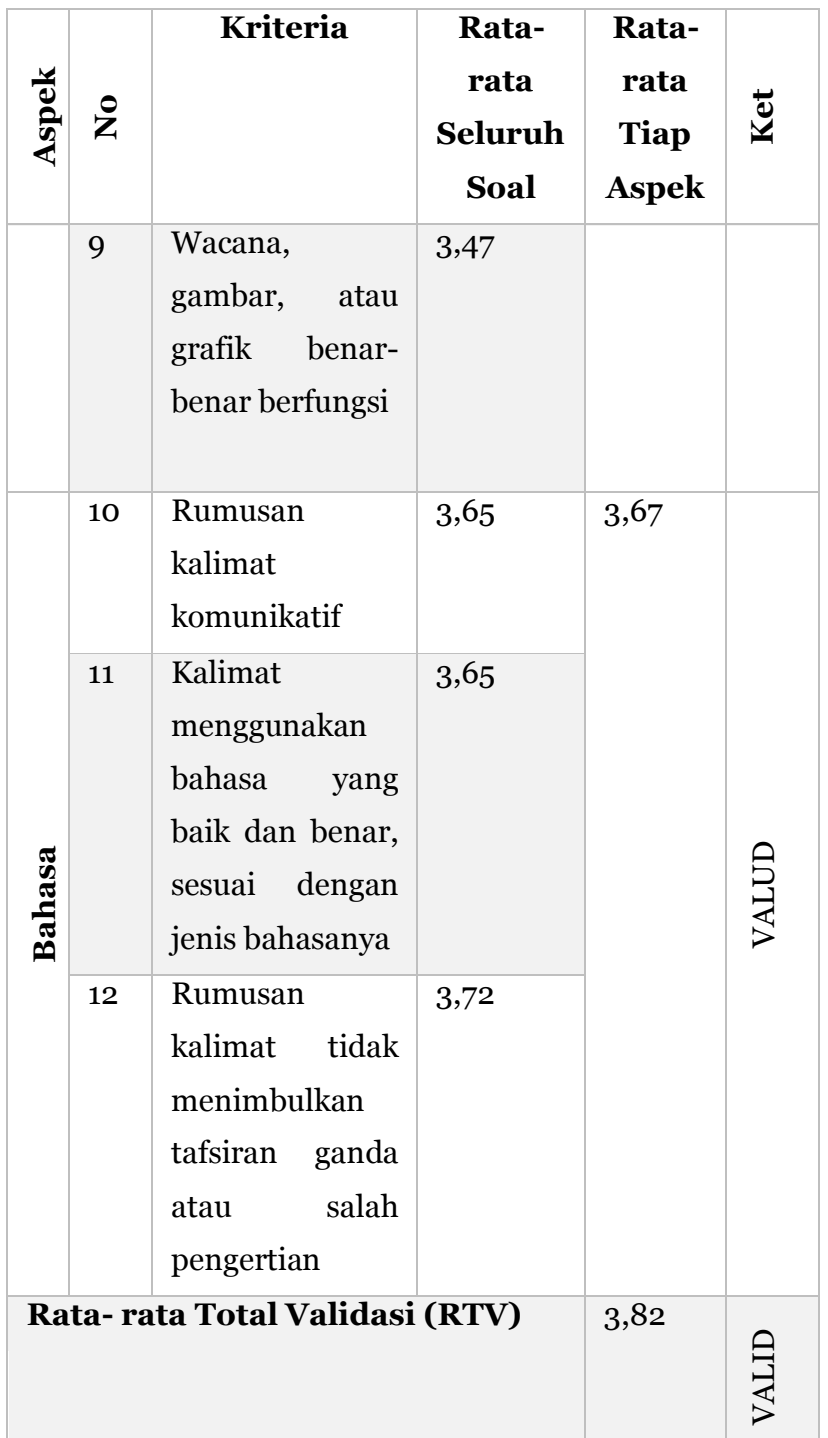

Tabel 1. merupakan hasil analisis berdasarkan hasil validasi ahli materi. Aspek materi mendapat nilai rata-rata tertinggi yaitu 3,98 dalam kategori valid. Hal ini menunjukkan bahwa isi materi yang ada pada soal sudah sesuai dengan materi yang telah mereka pelajari. Sedangkan pada aspek kontruksi soal mendapatkan nilai rata-rata 3,83 dalam kategori valid. Hal ini menunjukkan bahwa kontruk yang digunakan pada soal sudah baik menurut validator.

\section{Analisis Butir Soal Uji Coba Skala Kecil}

Analisis Butir Soal Pilihan Ganda

Berdasarkan hasil perhitungan reliabilitas instrumen soal matematika bernuansa islami diketahui bahwa soal tersebut reliabel dengan nilai sebesar 0,57 dengan interpretasi cukup baik. Hasil validasi butir soal ini didapatkan setelah dilakukan analisis butir soal bahwa meskipun hampir semua butir soal pilihan ganda merupakan soal yang valid, namun masih ada soal yang tidak valid yaitu pada butir soal nomor 1. Sehingga secara keseluruhan jika ditinjau dari validitas secara empiris soal matematika bernuansa islam pada soal pilihan ganda merupakan soal yang kurang baik atau masih ada soal yang harus di perbaiki.

Butir-butir soal matematika bernuansa islami dapat dikatakan baik apabila butir-butir tes tersebut memiliki daya pembeda paling kecil adalah 0,20 hal ini menunjukkan bahwa butirbutir soal memiliki daya pembeda minimal sedang, daya pembeda item instrumen tes yang dikembangkan diperoleh dari data hasil jawaban yang dikerjakan oelh siswa pada uji coba dalam skala kecil. ada beberapa kategori daya pembeda pada tahap uji coba yang dibagi ke dalam empat kategori yaitu buruk, sedang, baik dan sangat baik. Butir soal yang memiliki daya pembeda sangat baik adalah butir soal nomor 2, 4, 6, 7, 9, ini artinya bahwa kelima butir soal tersebut dapat membedakan siswa yang pandai dan kurang pandai dengan sangat baik. Butir soal yang memiliki daya pembeda baik adalah butir soal nomor 8 , artinya butir soal nomor 8 juga dapat membedakan siswa pandai dan kurang pandai dengan baik.Butir soal yang memiliki daya pembeda sedang adalah butir soal nomor 3, artinya butir soal nomor 3 sudah cukup dapat membedakan siswa pandai dan kurang pandai, dan butir soal yang memiliki daya pembeda buruk adalah butir soal nomor 5, 1, 10, artinya ketiga butir soal tersebut 
tidak dapat membedakan siswa pandai dan kurang pandai.

Ada beberapa kategori tingkat kesukaran pada tahap uji coba yaitu soal yang tergolong mudah dan sedang. Butir soal yang tergolong kategori mudah adalah butir soal nomor 1, 3, 5, dan 8 . Butir soal yang tergolong kategori sedang adalah butir soal nomor 2, 4, 6, 7, 9 dan 10. Sedangkan untuk butir soal yang termasuk kedalam kategori sukar untuk butir soal bentuk pilihan ganda tidak ada. Sesuai kriteria kualitas instrumen tes, terdapat butir soal pada pilihan ganda yang harus diperbaiki apabila akan digunakan pada uji coba selanjutnya karena masih ada 4 butir soal yang termasuk kedalam kategori mudah yaitu nomor 1, 3, 5, dan 8 .

\section{Analisis Butir soal Uraian}

\section{Reliabilitas}

Berdasarkan hasil perhitungan reliabilitas instrumen soal matematika bernuansa islami diketahui bahwa soal uraiantergolong reliabel dengan nilai sebesar 0,94 dengan interpretasi sangat baik. Hal ini berarti, instrumen tes untuk mengukur kemampuan siswa dalam mengerjakan soal uraian matematika bernuansa islami tergolong reliabel. Artinya instrumen tes yang telah dikembangkan dapat dipercaya dan memberikan hasil yang sama apabila tes ini dilakukan pada subjek, tempat maupun kondisi yang berbeda. Bahwa meskipun setiap butir soal pilihan ganda merupakan soal yang valid, namun masih ada soal yang tidak valid yaitu pada butir soal nomor 2 dan nomor 4. Sehingga secara keseluruhan jika ditinjau dari validitas secara empiris soal matematika bernuansa islam pada soal pilihan ganda merupakan soal yang kurang baik atau masih ada beberapa soal yang harus di perbaiki.
Butir-butir soal matematika bernuansa islami dapat dikatakan baik apabila butir-butir tes tersebut memiliki daya pembeda paling kecil adalah 0,20 hal ini menunjukkan bahwa butirbutir soal memiliki daya pembeda minimal sedang, daya pembeda item instrumen tes yang dikembangkan diperoleh dari data hasil jawaban yang dikerjakan oleh siswa pada uji coba dalam skala kecil. Butir soal yang memiliki daya pembeda sangat baik adalah butir soal nomor 3, 4, 7, 10 ini artinya bahwa keempat butir soal tersebut dapat membedakan siswa yang pandai dan kurang pandai dengan sangat baik. Butir soal yang memiliki daya pembeda baik adalah butir soal nomor 5, 6, 8, 9. Artinya butir soal tersebut dapat membedakan siswa yang pandai dan kurang pandai dengan baik. Butir soal yang memiliki daya pembeda sedang adalah butir soal nomor 1, artinya butir soal nomor 1 sudah cukup dapat membedakan siswa pandai dan kurang pandai, dan butir soal yang memiliki daya pembeda buruk adalah butir soal nomor 2. Artinya butir soal tersebut tidak dapat membedakan siswa yang pandai dan kurang pandai.

Ada beberapa kategori tingkat kesukaran pada tahap uji coba yaitu soal yang tergolong mudah,sedang dan sukar. Butir soal yang tergolong kategori mudah adalah butir soal nomor 1 dan 2. Butir soal yang tergolong kategori sedang adalah butir soal nomor 3, 4, 6, 7, 8 dan 10. Sedangkan untuk butir soal yang termasuk kedalam kategori sukar adalah butir soal nomor 5 dan 9 .

Sesuai kriteria kualitas instrumen tes, terdapat butir soal uraian yang harus diperbaiki apabila akan digunakan pada uji coba selanjutnya karena masih ada 2 soal yang termasuk kedalam kategori mudah dan 2 soal yang termasuk kedalam kategori sukar. 
Nunung Sobarningsih, Juariah

Rikrik Nurdiansyah, Ayu Retno Purwanti

Rahayu Kariadinata

\section{Analisis Butir Soal Uji Coba Skala Besar}

Analisis Butir Soal Pilihan Ganda

Berdasarkan hasil perhitungan reliabilitas instrumen soal matematika bernuansa islami diketahui bahwa soal tersebut reliabel dengan nilai sebesar 0,82 dengan interpretasi baik. Hal ini berarti, instrumen tes untuk mengukur kemampuan siswa dalam mengerjakan soal matematika bernuansa islami tergolong reliabel. Artinya instrumen tes yang telah dikembangkan dapat dipercaya dan memberikan hasil yang sama apabila tes ini dilakukan pada subjek, tempat maupun kondisi yang berbeda. Setiap butir soal pilihan ganda merupakan soal yang valid, meskipun hanya ada 3 butir soal yang memiliki koefisien kolerasi yang ditafsirkan tinggi yaitu pada butir soal nomor 8, 9, dan 10. Sementara untuk 7 butir soal lainnya memiliki koefisien kolerasi yang ditafsirkan cukup. Sehingga secara keseluruhan jika ditinjau dari validitas secara empiris soal matematika bernuansa islam pada soal pilihan ganda merupakan soal yang cukup baik.

Beberapa kategori daya pembeda pada tahap uji coba yang dibagi ke dalam empat kategori yaitu buruk, sedang, baik dan sangat baik. Daya pembeda ialah bagaimana kemampuan soal untuk membedakan siswa yang termasuk pandai dan siswa yang kurang pandai (Purwanto, 2013, hal. 120). Pada soal pilihan ganda semua butir soal sudah memiliki daya pembeda yang baik, ini artinya bahwa semua butir soal tersebut dapat membedakan siswa yang pandai dan kurang pandai dengan baik.

Terdapat kategori tingkat kesukaran pada tahap uji coba yaitu soal yang tergolong mudah dan sedang. Butir soal yang tergolong kategori mudah adalah butir soal nomor 3, 4 dan 7. Butir soal yang tergolong kategori sedang adalah butir soal nomor 1, 2, 5, 6, 8, 9 dan 10. Sedangkan untuk butir soal yang termasuk kedalam kategori sukar untuk butir soal bentuk pilihan ganda tidak ada. Sesuai kriteria kualitas instrumen tes, terdapat butir soal pada pilihan ganda yang harus diperbaiki apabila akan digunakan pada uji coba selanjutnya karena masih ada 4 butir soal yang termasuk kedalam kategori mudah yaitu nomor 3, 4, dan 7 .

Analisis Butir soal Uraian

Berdasarkan hasil perhitungan reliabilitas instrumen soal matematika bernuansa islami diketahui bahwa soal tersebut reliabel dengan nilai sebesar 0,93 dengan interpretasi sangat baik. Hal ini berarti, instrumen tes untuk mengukur kemampuan siswa dalam mengerjakan soal matematika bernuansa islami tergolong reliabel. Setiap butir soal pilihan ganda merupakan soal yang valid, dan semua butir soal rata-rata sudah memiliki validitas yang tinggi. Sehingga secara keseluruhan jika ditinjau dari validitas secara empiris soal matematika bernuansa islam pada soal pilihan ganda merupakan soal yang baik.

Semua butir soal uraian memiliki daya pembeda yang baik, ini artinya bahwa semua butir soal uraian tersebut dapat membedakan siswa yang pandai dan kurang pandai dengan baik. Tingkat kesukaran soal matematika bernuansa islami yang dikembangkan juga diperoleh dari hasil jawaban soal uraian yang dikerjakan siswa pada saat uji coba skala besar. ada beberapa kategori tingkat kesukaran pada tahap uji coba yaitu soal yang tergolong mudah,sedang dan sukar. Pada hasil uji coba soal uraian dalam skala besar ini semua butir soal termasuk ke dalam kategori sedang sehingga sesuai dengan kriteria tes bahwa soal uraian matematika bernuansa islami ini sudah baik karena butir-butir soal instrumen tes dapat dikatakan baik apabila butir-butir tes tersebut memiliki tingkat kesukaran yang sedang, hal ini menunjukkan 
bahwa butir-butir soal tidak terlalu sulit dan tidak terlalu mudah(Purwanto, 2013, hal. 124). Contoh soal bernuansa Islami Pondok Pesantren AR-Ridwan mewajibkan santrinya untuk dapat menyetor hafalan Al-Qur'an minimal 3 ayat setiap hari. Ibnu merupakan santri pondok pesantren tersebut dan termasuk salah satu santri yang hafalannya paling banyak. Setiap hari Ibnu mampu menyetor 5 ayat. Tentukan banyaknya hafalan Ibnu selama 14 hari!. Konteks masalah yang disajikan bernuansa Islami kegiatan santri pada pondok pesantren menyetor hapalan A-Qur'an. Contoh soal lainnya: Dalam Al-Qur'an Surat Al-Baqarah ayat 261 yang artinya: "Perumpamaan orang yang mengifakkan hartanya di jalan Allah seperti sebutir biji yang menumbuhkan tujuh tangkai, pada setiap tangkai ada seratus biji. Allah melipat gandakan bagi siapa yang Dia kehendaki, dan Allah Maha luas, Maha Mengetahui."Ibnu mempunyai harta warisan peninggalan orangtuanya sebesar Rp. 340.000,-. Jika Ibnu ingin menyedekahkan 1/4 harta tersebut untuk pembangunan masjid. Berapakah pahala yang didapat Ibnu menurut perhitungan ayat diatas?

Tabel 2. Contoh Soal Bernuansa Islam Sebelum dan Sesudah di Revisi

\begin{tabular}{|c|c|c|}
\hline $\begin{array}{c}\text { No } \\
\text { Soal }\end{array}$ & Sebelum Revisi & Setelah Revisi \\
\hline $\mathbf{1}$ & $\begin{array}{l}\text { Shalat subuh adalah shalat yang harus } \\
\text { dijaga betul pelaksanaannya, sebab } \\
\text { tidak semua orang bisa konsisten, } \\
\text { bahkan shalat ini terasa berat bagi } \\
\text { orang-orang munafik. Berikut ini data } \\
\text { jumlah jamaah yang melaksanakan } \\
\text { shalat subuh di mesjid Al- Ikhlas } \\
\text { selama 10 hari terakhir (dalam jumlah } \\
\text { orang) }\end{array}$ & $\begin{array}{l}\text { Salah satu keutamaan shalat subuh adalah } \\
\text { mendapatkan jaminan dan rasa aman dari } \\
\text { Allah SWT, maka dari itu mesjid Al- Ikhlas } \\
\text { selalu penuh dihadiri oleh jamaah, Berikut } \\
\text { ini data jumlah jamaah yang melaksanakan } \\
\text { shalat subuh di mesjid Al- Ikhlas selama } 10 \\
\text { hari terakhir (dalam jumlah orang) }\end{array}$ \\
\hline 2 & $\begin{array}{l}\text { Imla merupakan bagian dari maharah } \\
\text { al-kitabah atau keterampilan menulis } \\
\text { al-qur'an. Berikut ini jumlah ayat yang } \\
\text { di tulis oleh } 7 \text { siswa pada saat tes imla }\end{array}$ & $\begin{array}{l}\text { Imla merupakan keterampilan menulis al- } \\
\text { qur'an yang termasuk dalam salah satu } \\
\text { aspek penilaian untuk syarat kenaikan kelas } \\
\text { di pesantren al-hidayah, berikut adalah } \\
\text { nilai yang diperoleh } 7 \text { santri al-hidayah }\end{array}$ \\
\hline
\end{tabular}


Nunung Sobarningsih, Juariah

Rikrik Nurdiansyah, Ayu Retno Purwanti

Rahayu Kariadinata

Berdasarkan tabel 2 soal bernuansa Islam dapat dikategorikan sebagai soal terintegrasi Islam dikarenakan konteks masalah yang disajikan berdasarkan kehidupan nyata siswa dalam beribadah. Hal ini dapat menjadikan pandangan bahwa matematika sangat bermanfaat bagi kehidupannya dan sekaligus mengingat atau mengenal agama Islam lebih baik lagi.

\section{KESIMPULAN}

Pada proses pengembangan menggunakan metode research and development (R\&D) dengan 10 tahapan yaitu potensi dan masalah, pengumpulan data, desain soal, validasi desain soal, revisi desain, uji coba terbatas, revisi soal hasil uji coba terbatas, uji coba soal, revisi hasil uji coba soal, produk akhir. Seluruh tahapan pada proses pengembangan dilaksanakan dengan baik dan sesuai dengan tahapan pengembangan research and development (R\&D). Kelayakan soal matematika bernuansa islami dinilai layak digunakan kerena telah memenuhi dua kriteria kelayakan soal yaitu: 1) soal matematika bernuansa islami memenuhi syarat kelayakan dari ahli materi, 2) soal matematika bernuansa memiliki ciri-ciri tes yang baik dengan reliabilitas yang sangat tinggi dan semua butir soal merupakan soal yang valid. Respon siswa pada soal matematika bernuansa islami mendapatkan status sangat baik dengan persentase $82,25 \%$. Dari total respon tersebut mengartikan bahwa siswa memiliki ketertarikan terhadap soal matematika bernuansa islami. Soal bernuansa Islam merupakan sesuatu hal yang baru bagi guru dan siswa, siswa belajar matematika dan agama secara langsung. Melalui soal bernuansa Islami siswa memahami dan mempelajari agama Islam secara tidak langsung, bagi siswa merasa tertantang untuk semakin menggali ilmu tentang agama Islam. 
Pengembangan Soal Matematika Bernuansa Islami

Perguruan Birrul Waalidain. Jurnal Abdimas, 14.
Yusuf, M. (2013). Membentuk Karakter Melalui Pendidikan Berbasis Nilai. Al-Ulum, 4. 